\title{
多径間連続鋼トラス橋の 交通振動を用いた損傷検知手法
}

\author{
金 哲佑 1 - 北内 壮太郎 $2 \cdot$ 杉浦 邦征 $^{3} \cdot$ 川谷 充郎 4 - 甲斐 正義 5 \\ 1正会員 京都大学大学院教授 工学研究科社会基盤工学専攻（广 $615-8540$ 京都市西京区京都大学桂） \\ E-mail: kim.chulwoo.5u@kyoto-u.ac.jp \\ 2学生員 京都大学大学院 工学研究科社会基盤工学専攻（ \\ E-mail: kitauchi.soutarou.43e@st.kyoto-u.ac.jp \\ 3 正会員 京都大学大学院教授 工学研究科社会基盤工学専攻（广615-8540 京都市西京区京都大学桂） \\ E-mail: sugiura.kunitomo.4n@kyoto-u.ac.jp \\ 4フェロー 神戸大学大学院教授 工学研究科市民工学専攻（テ657-8501 神戸市灘区六甲台町1-1） \\ E-mail: m-kawa@kobe-u.ac.jp \\ ${ }^{5} \mathrm{NEC}$ システムテクノロジー株式会社（テ630-0101 奈良県生駒市高山町8916-47） \\ E-mail: kai-mxa@necst.nec.co.jp
}

\begin{abstract}
本研究では, 既存のゲルバー鋼トラス橋の一部材を破断させ, 大型車両の繰り返し走行から得られる橋 梁振動応答により実橋の時系列線形システムモデルのシステムパラメータを同定することで, 橋梁へルス モニタリングを行う可能性について検討した．橋梁損傷検知のための指標として橋梁の固有振動数および 減衰定数に加え, 本研究では自己回帰モデルのモデル係数(AR係数)で構成される損傷検知指標(Damage Indicator: DI)も採用し, 損傷前後の変化を調べた. DIは推定の際のばらつきが小さく, 損傷導入位置付近 で損傷前後の変化が相対的に大きくなる傾向が見られた．また，統計的分析の一手法である MahalanobisTaguchi System (MTS)をDIに適用した結果，橋梁の損傷検知の実現可能性を確認した.
\end{abstract}

Key Words : damage indicator, fault detection, linear system model, Mahalanobis-Taguchi System (MTS), traffic-induced vibration, truss bridge

\section{1. はじめに}

現在，我が国の橋梁ストックのうち，高度経済成長期 に建設された橋梁は約 $50 \%$ を占めており ${ }^{1)}$, 近い将来, 橋梁点検により多くの橋梁に対して補修・補強などの意 思決定を行う必要が生じると予想される，また，橋梁ス トックの大部分を中小スパン橋梁が占めていることから, 中小スパン橋梁を対象とした異常検知手法の開発が喫緊 の課題であると考える ${ }^{1)}$. 特に, 2007年に発生した米国 ミネアポリスの高速道路橋崩壊事故2)，木曽川大橋・本 庄大橋での斜材破断事故引および筒井大橋での斜材腐食 損傷3などは，いずれも中小スパンの鋼トラス橋におけ る重大事故である. 今後も同様な事故が鋼卜ラス橋で発 生する可能性が益々高まると考えられる. したがって, 鋼卜ラス橋を効率的に維持管理する上で，橋梁の状態に ついて簡易かつ迅速な意思決定を行うことが出来る経済 的な手法の開発は重要な研究課題である.
異常検知のための手法は様々提案されているが，その 手法の一つとして振動へルスモニタリングが挙げられる. 通常, 構造物に損傷が生じると, 構造物の固有振動数や 減衰定数, モード形状といった振動特性の変化として現 れることから，振動モニタリングによる橋梁の異常検知 は有効であると報告されている(4)-14)，ただし，振動へル スモニタリングの実用化に向けた課題としては, 構造物 に動的外力をどのように与えるかが挙げられる. 例えば 大型加振装置を用いて構造物の振動特性を把握すること は可能であるが，交通規制を要することになり実用的で なく，また，一般的に費用が高い，一方，中小スパン橋 梁では車両走行による振動が卓越することから, 日常的 な車両走行による交通振動に着目した異常検知が可能に なれば，加振装置を用いる必要もなく実用的である。

交通振動に基づくへルスモニタリングの場合に留意し なければならないのは，車両一橋梁の連成振動の非定常 性である ${ }^{11,15-177}$. すなわち, 移動車両の橋梁系への影響 
である非定常性 ${ }^{155}$ にっって，橋梁系に関わるシステムパ ラメータにはばらつきが発生しやすくなる．したがって, システムパラメータのばらつきまでを考慮した統計的な アプローチを構築し，損傷検知および損傷位置の推定が 可能な手法の確立が望まれる.

これまでに，著者ら ${ }^{14,18,19}$ は室内での模型橋梁を用い た実験において，交通振動を用いた振動モニタリングに よる異常検知手法の開発を行っている，具体的には，ま ず，健全状態での模型橋梁上に模型車両を繰り返し走行 させ，交通振動から得られる種々のシステムパラメータ (振動数, 減衰定数, モード形状, Damage Indicator (DI))を 統計的に処理することで，健全時の観測情報が持つ統計 的特性(平均，標準偏差，Mahalanobis Distance (MD)など)を 求めた。 その後，模型橋梁に段階的に損傷を与え，健全 時と同様に，各損傷段階でシステムパラメータが持つ統 計的特性を調へ，健全時と損傷時の統計的特性の比較に よる異常検知手法の提案を行った.この結果，模型橋梁 においては，提案した手法で異常検知が可能であること を確認している．しかしながら，実用化に際しては実橋 梁に検知の対象となる損傷を与え，損傷によるシステム パラメータの変化を確認する必要がある，そこで，本研 究では供用 40 年が経過し，現在は使用されていないゲル バ一鋼トラス橋において部材の一部を破断させ，部材破 断前後で車両走行による振動計測を行い，損傷検知およ び損傷位置の推定について検討を行う。

また，鋼トラス橋の振動ヘルスモニタリングについて の既往の関連研究として，吉岡ら ${ }^{20}$ は鋼トラス橋に対す る損傷実験において，車両通過後の自由振動から算定さ れる減衰比に着目した構造健全度評価の実現可能性につ いて検討を行っており，結論として，高次モードの減衰 比に着目寸れば損傷検知ができるとの結論を得ている.

しかし，多点同期計測データを用い，理論モード解析お よび実験モード解析双方による精緻な全体振動モード解 析を前提とした手法であるため，よりシンプルな手法を 開発する必要があると言える，なお，吉岡らは損傷位置 推定についての検討は行っていない.

こうした背景を踏まえ，本研究ではまず，線形システ ムモデル ${ }^{20-299}$ の一つである自己回帰モデル(AR：Auto Regressive Model )により振動特性の推定を行い，振動特 性に着目した損傷検知および損傷位置の推定の可能性を 検討する. その上でさらに, パターン分析手法の一つで あるMahalanobis-Taguchi System (MTS) $)^{30}$ を適用し，長期モ ニタリングのような，車両の繰り返し走行から得られる 計測データの統計的な処理による橋梁の異常検知の可能 性についても検討する.

なお，ARモデルにより推定される振動数，減衰定数 およびモード形状の変化に着目した従来の異常検知手法 においては，最適モデルの決定と3つのモードパラメー
夕による意思決定の難しさおよび推定すべき振動特性の 安定的抽出の煩雑さが指摘されている ${ }^{20)}$. そこで本研究 ではこうした従来の着目指標を用いる手法の課題を解决 すべく, AR係数で構成される損傷指標DI (Damage Indicator) ${ }^{14331)}$ を用い，DIに対してもMTSを適用し，損傷検知お よび損傷位置の推定の可能性について検討を行う。すな わち，DIを用いることで，先に述べた簡易な異常検知手

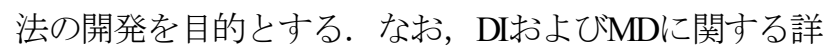
しい説明は第2章および第3章で行う。

\section{2. 線形システムモデル}

車両一橋梁連成振動系の橋梁系は，移動車両による非 定常性の影響を受けるため非定常系となるが，車両によ る非定常性は橋梁の定常振動周りの変動 ${ }^{15}$ として考慮で きる. 本研究では車両一橋梁連成系の橋梁系の振動を AR モデルで定式化し，同定する AR モデルのばらつき も考慮し，異常検知に挑む.

線形動的システムの出力の時系列 $y(k)$ が, $p$ 次 $\mathrm{AR}$ モ デル 2728)にしたがって発生すると仮定すると式(1)のよう に定式化できる.

$$
y(k)=\sum_{i=1}^{p} a_{i} y(k-i)+e(k)
$$

ここで, $y(k)$ はシステムの出力を, $a_{i}$ は $\mathrm{AR}$ 係数を,$e(k)$ は䛊差項を示す.

システムの出力の観測データの自己相関関数は式(2) で定義できる.

$$
\begin{aligned}
& \mathrm{R}_{k-s}=\mathrm{E}[y(i-s) y(i-k)] \\
& \mathrm{R}_{k}=\mathrm{R}_{-k}
\end{aligned}
$$

ここで，E[ ]は数学的平均值を示す. 式(2)を用いると, 次式に示寸 Yule-Walker 方程式 18220332)が得られる.

$$
\mathbf{R a}=-\mathbf{r}
$$

式(3)の R，aおよびrはそれぞれ式(4-1)，(4-2)および(4-3) で表される.

$$
\begin{gathered}
\mathbf{R}=\left[\begin{array}{cccc}
\mathrm{R}_{0} & \mathrm{R}_{1} & \cdots & \mathrm{R}_{p-1} \\
\mathrm{R}_{1} & \mathrm{R}_{0} & \cdots & \mathrm{R}_{p-2} \\
\vdots & \vdots & \ddots & \vdots \\
\mathrm{R}_{p-1} & \mathrm{R}_{p-2} & \cdots & \mathrm{R}_{0}
\end{array}\right] \\
\left.\mathbf{a}=\mid \begin{array}{llll}
a_{1} & a_{2} & \cdots & a_{p}
\end{array}\right\rfloor \\
\mathbf{r}=\left[\begin{array}{llll}
\mathrm{R}_{1} & \mathrm{R}_{2} & \cdots & \mathrm{R}_{p}
\end{array}\right]
\end{gathered}
$$

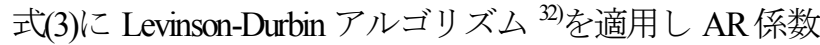
の推定を行う。なお，式(1)を z変換して得られる式(5)に 示すように，AR 係数はシステムの極と関係がある点に 留意する必要がある.

$$
Y(\mathrm{z})=H(\mathrm{z}) E(\mathrm{z})=\frac{1}{1+\sum_{i=1}^{p} a_{i} z^{-i}} E(z)
$$

ここで， $Y(z)$ および $E(z)$ はそれぞれ $y(k)$ および $e(k)$ を $\mathrm{z}$ 変 
換したものであり, $H(z)$ はシステムの伝達関数を， $z^{i}$ は 時間遅れ演算子を示す. 伝達関数の分母は, 式(6)に示 すようにシステムの特性方程式となる.

$$
z^{p}+a_{1} z^{p-1}+a_{2} z^{p-2}+\cdots+a_{p-1} z^{1}+a_{p}=0
$$

式(6)に示寸特性方程式の根 $z_{k}$ は, 以下の式に示すように 動的システムの振動数および咸衰定数と関係がある.

$$
z_{k}=\exp \left(-h_{k} \omega_{k} \pm j \omega_{k} \sqrt{1-h_{k}^{2}}\right)
$$

ここで， $\omega_{k}$ および $h_{k}$ はそれぞれ $k$ 次の固有円振動数およ び減衰定数を示し, $j$ は虚数単位を表す．また，多項式 理論よりシステムの極と AR 係数との関係は;

$$
\sum_{i=1}^{p} z_{i}=-a_{1} ; \sum_{i=1}^{p} \sum_{j=1}^{p} z_{i} z_{j}=-a_{2} ; \cdots
$$

となり, AR 係数とシステムの振動特性は直接関わって いることが明らかである．構造物に損傷が生じると振動 特性は変化するため, したがって $\mathrm{AR}$ 係数も変化する ${ }^{19}$. なお，本研究では最適次数である $p$ 次 $\mathrm{AR}$ モデルの $\mathrm{AR}$ 係数の内，式(9)に示寸ように 3 次までの AR 係数から得 られる $\mathrm{DI}^{14,31)}$ を損傷検知指標として用いる。 なお何次ま での AR 係数を分母に用いて正規化を行うかについては, 感度解析等の様々な検討が必要であるが，本研究では既 往の研究結果 ${ }^{14,193,311}$ に従い, 3 次までの $\mathrm{AR}$ 係数を考慮 する式(9)の形式を採用するに至った.

$$
\mathrm{DI}=\left|a_{1}\right| / \sqrt{a_{1}^{2}+a_{2}^{2}+a_{3}^{2}}
$$

以上より, 車両一橋梁連成システムの振動数, 減衰定 数および損傷指標 DI を推定し, 異常検知を行う.

\section{Mahalanobis-Taguchi System (MTS)}

本研究では，得られた橋梁の振動特性および DI より, 橋梁が正常あるいは異常であるかの意思決定を行うため, MTS を適用寸る. MTS はパターン分析手法の一つであ り，既知のデータと未知のデータの Mahalanobis Distance (MD) と呼ばれる統計学的距離を求めることで定量的に データの類似性を明らかにする手法である ${ }^{30)}$.

MD の概念を Fig.1 に示寸 ${ }^{19}$. 一一般に広く用いられて いるユークリッド距離と異なり, MD は統計的性質の近 さを表す距離である．例えば，Fig.1 に例示する青線で 描かれた楕円内にある青丸で構成されるデータ群は統計 的に同じ性質を持つと仮定する。ここで，図中に例示す る赤バツで構成されるデータ群と緑三角で構成されるデ 一タ群に対して，ユークリッド距離として MD1 および MD2 は同程度であるが，青丸データ群と統計的に同じ か同じでないかの統計的性質は異なる.

本研究ではまず, 健全時における橋梁(健全であると みな寸橋梁)の振動特性を表す諸数值および DI $の \mathrm{MD}$ (既 知のデータの $\mathrm{MD}$ ) と，新たな計測データより推定する 橋梁の振動特性を表す諸数值および DI の MD (未知のデ

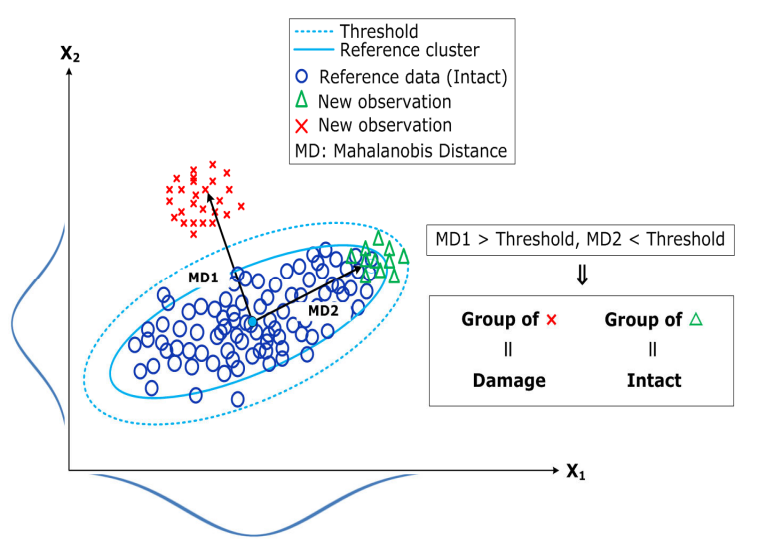

Fig.1 Concept of Mahalanobis Distance (MD).

ータの MD)を求める. その後, 既知のデータを用いて 設定した閾值を超える未知のデータの MD の個数およ びその量を調べ，未知のデータが橋梁の健全状態と損傷 状態のどちらを表すものなのかを判定する．以下に MTS 適用の手順を示す.

既知のデータを式(10)のように表す。

$$
\mathbf{x}=\left[\begin{array}{ccccc}
x_{11} & \cdots & x_{1 i} & \cdots & x_{1 k} \\
\vdots & \ddots & \vdots & \ddots & \vdots \\
x_{p 1} & \cdots & x_{p i} & \cdots & x_{p k} \\
\vdots & \ddots & \vdots & \ddots & \vdots \\
x_{n 1} & \cdots & x_{n i} & \cdots & x_{n k}
\end{array}\right]
$$

式(10)において, 列数は項目数（特徵量, $k$ 個）を示し, 行数は観測数（ $n$ 個）を示している. それぞれの項目 (特徵量) ごとに平均および標準偏差を求め，以下に示 すようにデータを標準化する.

$$
X_{p i}=\left(x_{p i}-\bar{x}_{i}\right) / \sigma_{i}
$$

ここで $\bar{x}_{i}$ と $\sigma_{i}$ は式(12) に定義される $i$ 番目の項目の既知 のデータにおける平均值および標準偏差である.

$$
\begin{aligned}
& \bar{x}_{i}=\frac{1}{n} \sum_{p=1}^{n} x_{p i} \\
& \sigma_{i}=\sqrt{\frac{1}{n} \sum_{p=1}^{n}\left(x_{p i}-\bar{x}_{i}\right)^{2}}
\end{aligned}
$$

標準化後のデータを用いて各項目間の相関係数を算出し, 式(13) に示寸相関係数行列を求める.

$$
\mathbf{R}_{\mathrm{MD}}=\left[\begin{array}{cccc}
1 & r_{12} & \cdots & r_{1 k} \\
r_{21} & 1 & \cdots & r_{2 k} \\
\vdots & \vdots & \ddots & \vdots \\
r_{k 1} & r_{k 2} & \cdots & 1
\end{array}\right]
$$

ここで，相関係数行列 $\mathbf{R}_{\mathrm{MD}}$ の各要素の相関係数 $r_{i j}$ は式 (14)より算出される.

$$
r_{i j}=\frac{\sum_{p=1}^{n} X_{p i} X_{p j}}{\sqrt{\left(\sum_{p=1}^{n} X_{p i}^{2}\right)\left(\sum_{p=1}^{n} X_{p j}^{2}\right)}}
$$

相関係数行列 $\mathbf{R}_{\mathrm{MD}}$ の逆行列を式(15)に示すように定義し 


$$
\mathbf{A}=\mathbf{R}_{M D}^{-1}
$$

以下の式(16)より, 既知のデータの $\mathrm{MD}$ を求める.

$$
\mathrm{MD}_{p}=\frac{1}{k}\left[\begin{array}{lll}
X_{p 1} & \cdots & X_{p k}
\end{array}\right] \cdot \mathbf{A} \cdot\left[\begin{array}{c}
X_{p 1} \\
\vdots \\
X_{p k}
\end{array}\right]
$$

次に，未知のデータを式(17)のように示す.

$$
\mathbf{y}=\left[\begin{array}{ccccc}
y_{11} & \cdots & y_{1 i} & \cdots & y_{1 k} \\
\vdots & \ddots & \vdots & \ddots & \vdots \\
y_{q 1} & \cdots & y_{q i} & \cdots & y_{q k} \\
\vdots & \ddots & \vdots & \ddots & \vdots \\
y_{m 1} & \cdots & y_{m i} & \cdots & y_{m k}
\end{array}\right]
$$

ここで， $m$ は観測数を表す. 式(12)に示す既知のデータ の平均值および標準偏差を用いて式(18)に示すように未 知のデータについても, 既知のデータの平均值および標 準偏差を用いて標準化を行う。

$$
Y_{q i}=\left(y_{q i}-\bar{x}_{i}\right) / \sigma_{i}
$$

未知のデータの $\mathrm{MD}$ は, 式(15)に示す既知のデータより 求めた相関関数行列の逆行列 $\mathbf{A}$ および式(18)に示寸標準 化後の未知のデータを用いて式(19)のように定義される.

$$
\overline{\mathrm{MD}}_{q}=\frac{1}{k}\left[\begin{array}{lll}
Y_{q 1} & \cdots & Y_{q k}
\end{array}\right] \cdot \mathbf{A} \cdot\left[\begin{array}{c}
Y_{q 1} \\
\vdots \\
Y_{q k}
\end{array}\right]
$$

なお，MTSを適用する際の条件として，

1. (既知のデータの項目数 $)=$ (未知のデータの項目数 $)$

2. 観測数 > 項目数

3. 既知のデータの標準偏差 $\sigma_{i}$ が 0 でない.

が挙げられるため，満足するよう設定する．なお，既知 のデータおよび未知のデータとも正規分布に従うものと する.これらの条件を満たせばMTSは適用できる.

次に閾值の設定方法について述べる。一般に MTS の 適用に際して, 統計的性質が異なると判断寸る MD の 闇值には 3〜5 が用いられる ${ }^{30}$. これは, 既知のデータ の MD の平均值が 1 になることが数学的に証明されてお り，それに安全率を考慮し 3〜5 としているためである. しかしながら橋梁の種類，設置状況などは様々であり一 律に閾值を設定するのは好ましくない，したがって，橋 梁ごとに閾值を変えて設定する必要があるが，それぞれ の橋梁で間值に関する意思決定を行うことは，簡易な異 常検知手法の開発という本研究の目標にはそぐわない. そこで本研究では，自動的に閾值設定を行うことを目的 とし, データ安定性を確認する手法である交差確認法 ${ }^{30}$ を用いて閾值の設定を行う。

本研究で用いる交差確認法による閾值の設定方法を以 下にまとめる. まず，式(10)に示す既知のデータ $(n$ 個)か ら(n-1)個のデータを選び，残り 1 個のデータを未知のデ 一タと仮定する. これら( $n-1)$ 個の既知のデータと 1 個の 未知と仮定したデータに MTS を適用させ，未知と仮定
したデータに対する MD を求める. 次に，別の既知の データを未知のデータと仮定し MTS を適用させ, 未知 と仮定したデータに対する $\mathrm{MD}$ を求める.このような 処理を $n$ 回繰り返し行い $n$ 個の MD を得る. 本研究では, $n$ 個の $\mathrm{MD}$ の内, 最大值と最小值を除いた $(n-2)$ 個の平均 值であるトリム平均を求め, これを閾值とする. 本研究 での異常判断基準としては，上記の閾值を用いた上で, 以下に挙げる 2 項目について確認する.

1)閾值を超える観測数の割合

2) 閾值を超えている $\mathrm{MD}$ の值の平均值

上記項目の両方が交差確認法の結果より大きければ損傷, 1 項目でも下回れば健全であると判断する.

なお，健全時のデータの中にも損傷と判定されるデー タが存在し，こうしたデータは MTS による損傷検知の 精度を下げる原因になるため, 本研究では, 健全である とみな寸データから閾值を超えるデータを削除し，異常 診断の基準となるデータを設定する.

\section{4. 実験概要}

\section{(1) 対象橋梁}

実橋梁において車両走行時の振動計測を行う。本研究 の対象橋梁を Fig.2 に示す. 対象径間は 9 径間連続ゲル バー鋼トラス橋の $\mathrm{A} 1$ 橋台から第 6 径間であり, 支間長 は $65.52 \mathrm{~m}$ である. 部材破断前後の振動計測結果から損 傷を検知できるかどうかを調査することが本研究の目的 であり，破断前の橋梁の状態を Intact(健全)とみな寸。

橋梁に与える損傷は, Fig.2 および Fig.3 の赤色で示し た車両進入側から 4 本目の斜材を破断させることで模擬 する. 老朽化した部材が破断した木曽川大橋や本庄大橋

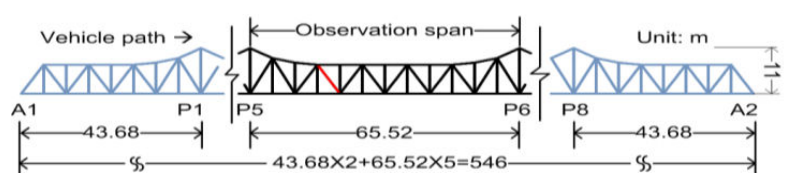

Fig.2Elevation view of the bridge.

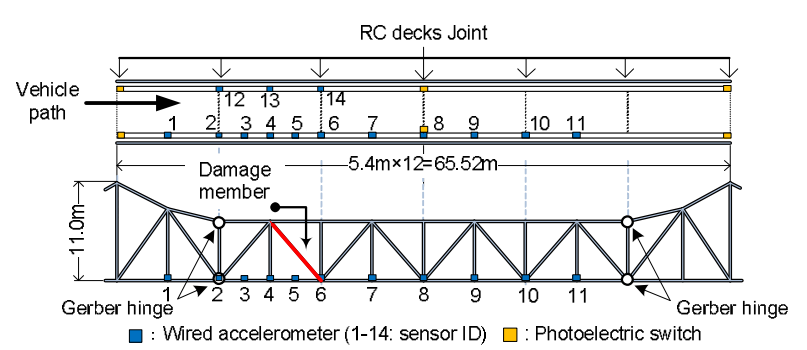

Fig.3Observation span and sensor deployment map. 
での事例を考慮し，破断シナリオとしては部材軸方向と 垂直方向に完全に破断するケースを想定する．部材の切 断時には，安全性を十分に考慮するために，Fig.4a)に示 すように，ゲビン鋼棒，センターホールジャッキ，鋼棒 を受ける鋼製ブラケットを設置し，切断前にセンターホ 一ルジャッキにて, 死荷重時の設計引張軸力 $(658 \mathrm{kN})$ 相 当の圧縮力を作用させ，部材に作用する荷重を鋼棒に持 たせた後，ガスバーナーによって溶断し，切断後徐々に ジャッキの力を緩めることで, 斜材に作用していた力を ゆっくりと開放する. さらにこのとき，過大な変位が生 じてもある変位で変形が止まるように，あらかじめ変位 制限部材を設置し，十分に安全に配慮して部材切断を進 める. 今回の実験では別途，部材破断時の衝撃力を測定 する計画も考えられたが，安全面を考慮した結果行わな いこととする．破断前後の 破断部材の様子を Fig.4b)お よびFig.4c)に示す.

振動計測でのサンプリング周波数は $200 \mathrm{~Hz}$ とし，橋梁 での計測点は損傷位置付近で密になるように設置し，14 測点とする (Fig. 3 参照). なお 14 個全ての有線加速度計 (東京測器 ARS-1, ARH-A : 共和電業 AS-GB)は Fig.5 に示 すように地覆上に設置し，データロガー(東京測器 DC204，DC104)を用いて橋軸鉛直方向の振動計測を行う.

\section{（2）走行車両, 車両走行シナリオ}

本実験で用いる走行車両を Fig.5 に示す. 走行車両は 荷台に $\mathrm{H}$ 鋼を積み, 総重量が $25 \mathrm{tf}$ になるように調整さ れている. 車両の動摇の計測点については前軸・後軸の バネ上およびバネ下の計 4 箇所に着目し，前軸バネ上と して運転席に，後軸バネ上として荷台下の後軸サスペン ション上部に，さらに前後軸それぞれのバネ下に加速度 センサ(東京測器 ARH-A)を取り付ける. 車両速度が異常 検知に与える影響を考慮し， $10 \mathrm{~km} / \mathrm{h} ， 20 \mathrm{~km} / \mathrm{h}$ および $40 \mathrm{~km} / \mathrm{h}$ に変化させ振動計測を行う. なお部材切断作業 を行うための作業スペースが設けられているため(Fig.4 参照), 車両の走行位置は切断斜材とは反対側の車線と する．車両と橋梁の計測機器は独立しているが，同時刻 にパルス電圧を入力することで時刻の同期を行う。具体 的には，毎回の走行後に同期用ケーブルと同期スイッチ を用いて同期させる. 光電センサ(Keyence: PZ-G52)を入 口・中央・出口に設置することで，車両通過時刻から車 両の走行位置の推定を行う.

車両走行シナリオと各シナリオにおける健全時および 損傷時の計測回数を Table 1 に，各軸重計測結果を Table 2 に示す。ここで，SCN1 は健全時の観測数が 4 と少ない ため, MTS による判定精度が悪くなると予想できる. そこで，全ての速度におけるデータを扱い観測数を増や して MTSを適用するシナリオとして，SCN4 を設定する.
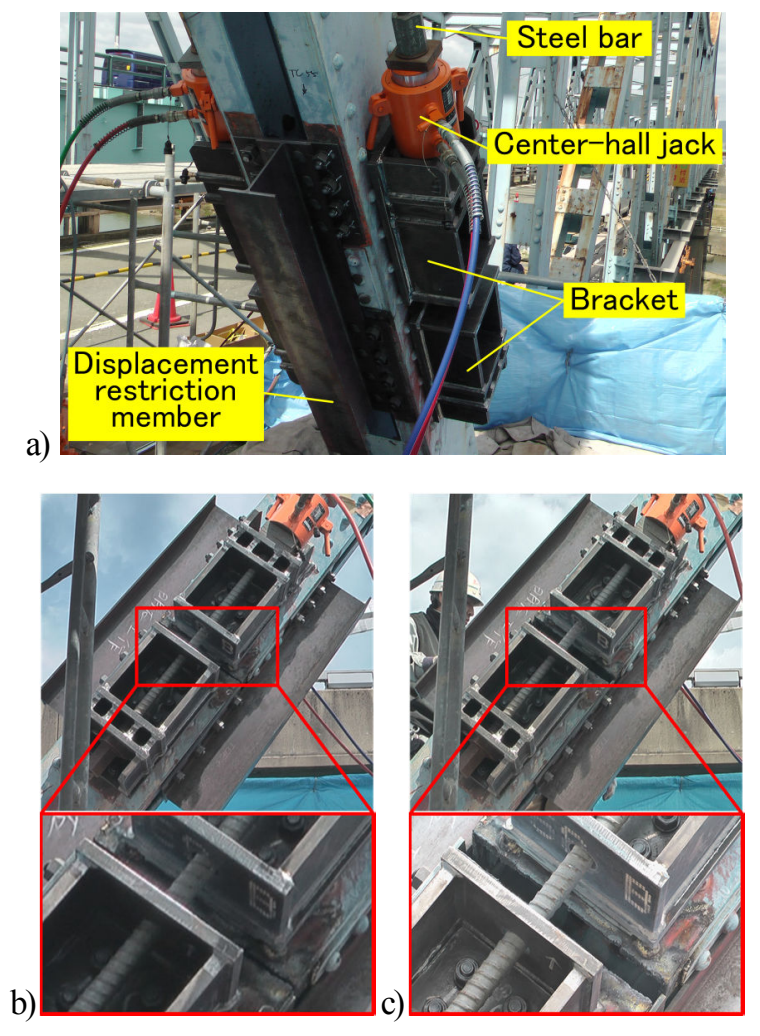

Fig.4 Photos of the cut member: a) instruments to cut the member; b) before releasing the compressive force; and c) after releasing the compressive force.

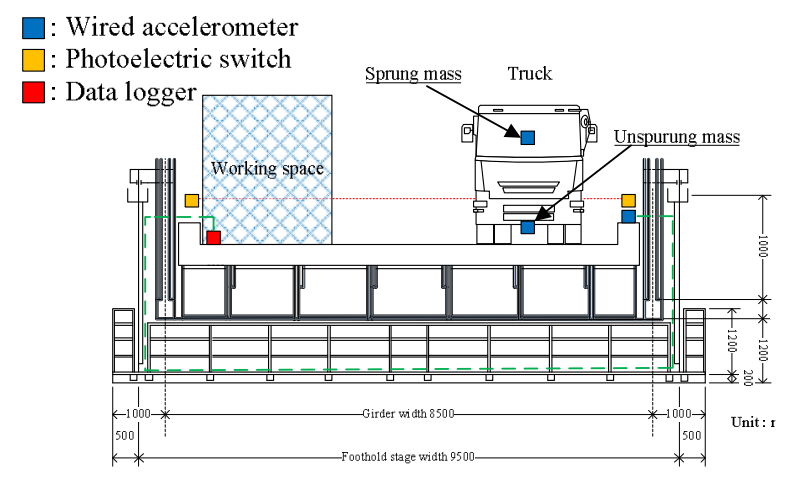

Fig.5Cross sectional view and vehicle loading.

Table 1 Scenario of moving vehicle test.

\begin{tabular}{cccc}
\hline \multirow{2}{*}{ Scenarios } & \multirow{2}{*}{ Speed } & \multicolumn{2}{c}{ The number of observations } \\
\cline { 3 - 4 } & & Intact & Damage \\
\hline SCN1 & $10 \mathrm{~km} / \mathrm{h}$ & 4 & 3 \\
SCN2 & $20 \mathrm{~km} / \mathrm{h}$ & 7 & 6 \\
SCN3 & $40 \mathrm{~km} / \mathrm{h}$ & 7 & 6 \\
SCN4 & Combination of SCN1, & 18 & 15 \\
& SCN2 and SCN3 & & \\
\hline
\end{tabular}

Table 2 Axle weight of test vehicle. Unit[kN]

\begin{tabular}{ccccc:cccc}
\hline \multicolumn{5}{c}{ First day } & & \multicolumn{4}{c}{ Second day } \\
\hline Axle & Front & Rearl & Rear2 & Front & Rear1 & Rear2 \\
\hline Left & 35.8 & 47.8 & 41.7 & & 37.0 & 47.7 & 41.9 & \\
Right & 34.1 & 48.1 & 45.7 & Total & 36.2 & 49.7 & 45.9 & Total \\
Total & 69.9 & 95.9 & 87.4 & 253 & 73.2 & 97.4 & 87.8 & 258 \\
\hline
\end{tabular}




\section{5. 振動特性に着目した異常診断}

\section{（1）振動特性推定}

対象橋梁の振動特性の推定には，多次元 ARモデル ${ }^{18229)}$ により推定される振動数の Stabilization Diagram と, Frequency Domain Decomposition (FDD) ${ }^{33}$ により求まる特異 值スペクトルを用いる. Fig.6a)および Fig.6b)はそれぞれ， 健全時および損傷時の SCN3 における Stabilization Diagram と振動数の特異值スペクトルである. 左側縦軸は多次元 $\mathrm{AR}$ モデルのモデル次数，右側縦軸は特異值スペクトル 值，横軸は振動数を表す．損傷前後とも $14.5 \mathrm{~Hz}$ 近傍の 振動数が卓越しているが，Fig.7 に示す測点 5 の wavelet 変換からわかるように，周期的に複数回卓越振動数が表 れていることから，スパンごとのジョイント部を車両が 通過する際の衝撃によるものであると考えられる. Fig.6 およびFig.7から， Stabilization Diagramおよび wavelet 変換 のみでは損傷検知が容易ではないことがわかる。なお AIC (Akaike Information Criteria ; 式(21)) ${ }^{28)}$ に基づくと多次元 $\mathrm{AR} モ テ ゙ ル の$ 最適モデル次数は 60 より大きくなるが，最 適モデル次数まで考慮することで推定される振動数の中 には，構造物の振動特性と直接関わりのない解が多く含 まれるため, 高次のモデル次数については考慮しないこ ととする.

本研究においては，健全時の Stabilization Diagram より
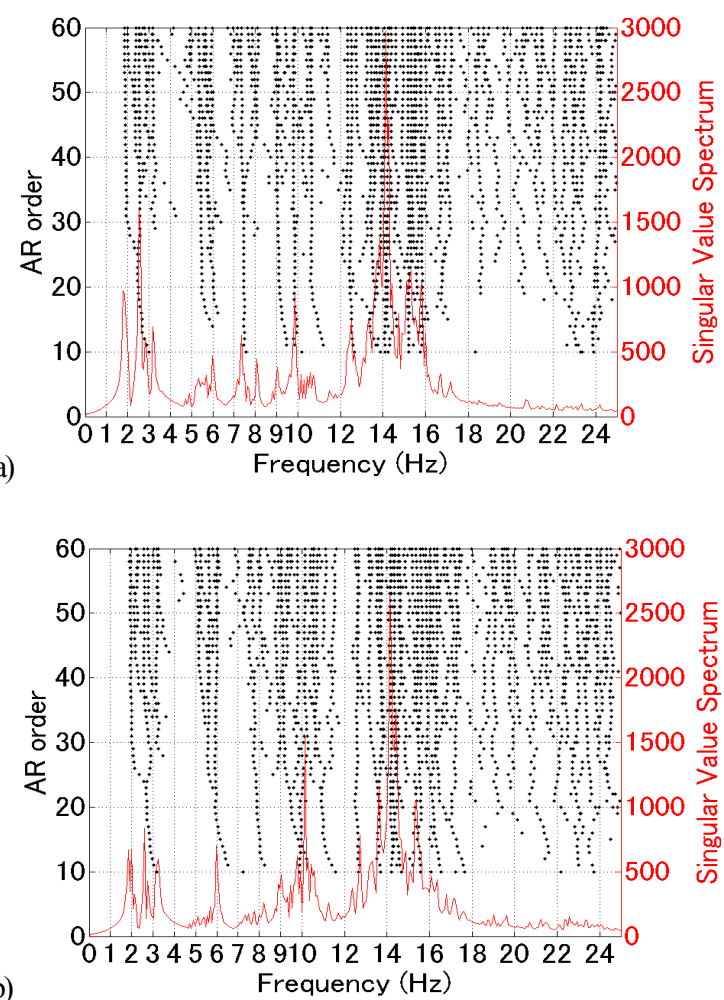

Fig.6 Stabilization Diagram and singular value spectrum under SCN3: a) Intact; and b) Damage.
安定的に推定される複数の振動数とそれに対応寸るモ一 ド形状を検討し，最も安定的に推定されている $1.96 \mathrm{~Hz}$ および $7.64 \mathrm{~Hz}$ の二つの卓越振動モードに着目する. 関 連振動モードを Fig.8 に示す。青線は測点 1 11 側のモー ド形状を，赤線は測点 12 14 側のモード形状を表す．各 車両走行シナリオにおける $1.96 \mathrm{~Hz}$ 近傍振動数および対 応する減衰定数の損傷前後の変化を付録 $\mathrm{A}$ に示す.

\section{(2) Coordinate Modal Assurance Criterion (COMAC)}

本節では損傷前後のモード形状の変化について, Coordinate Modal Assurance Criterion (COMAC) ${ }^{34)}$ 用いて検
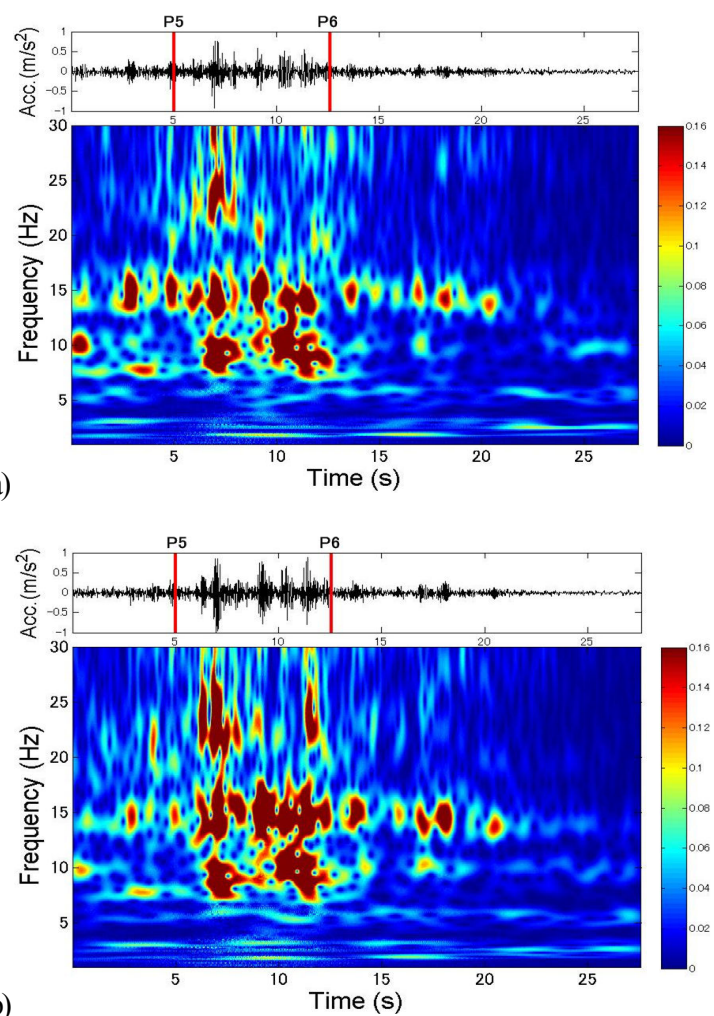

Fig.7 Wavelet transform of acceleration response observed at point 5 under SCN3: a) Intact; and b) Damage.

a)

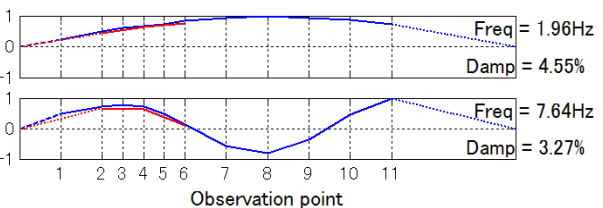

b)

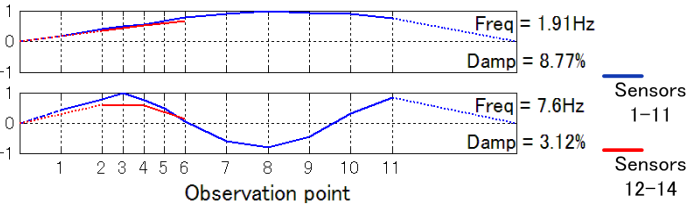

Fig.8 Average mode shapes of two dominant mode shapes and corresponding frequency and damping constant: a) Intact; and b) Damage. 
討する. COMAC はモード形状の相関を観測点毎に算出 する指標であり，式(20)より算出される. COMAC は 0 から 1 の值を持ち，1 に近いほど相関が強いことを表す。

$$
\operatorname{COMAC}(r)=\frac{\left(\sum_{i}^{N}\left\{\boldsymbol{\varphi}_{i}^{I n}(r)\right\}^{T}\left\{\boldsymbol{\varphi}_{i}^{D m}(r)\right\}^{T}\right)^{2}}{\left(\sum_{i}^{N}\left\|\boldsymbol{\varphi}_{i}^{I n}(r)\right\|^{2}\right)\left(\sum_{i}^{N}\left\|\boldsymbol{\varphi}_{i}^{D m}(r)\right\|^{2}\right)}
$$

ここで， $r$ は観測点， $\boldsymbol{\varphi}_{i}^{I n}$ は健全時における $i$ 次モード形 状， $\boldsymbol{\varphi}_{i}^{D m}$ は損傷時における $i$ 次モード形状， $N$ は考慮す るモード形状の個数をそれぞれ表す. 本研究では 1 次モ ードとして $1.96 \mathrm{~Hz}$ 近傍の振動数に対応するモード形状 を，2 次モードとして $7.64 \mathrm{~Hz}$ 近傍の振動数に対応するモ 一ド形状を用いるため, $N=2$ とする. 車両走行シナリオ SCN4 に対して, 健全時の平均モード形状を求め, 損傷 時の 15 個のモード形状との COMAC 值を計算する.

Fig.9a)に全計測点での COMAC 值を, Fig.9b)に格点部の みの計測点での COMAC 值を示す．なお Fig.9 に示すの は 15 個の COMAC 值の平均である. Fig.9a)より，損傷位 置付近の計測点である計測点 5 から 6 に加え, 損傷位置 の反対車線に相当する計測点 14 における COMAC の值 が相対的に小さいことがわかる，一方 Fig.9b)より，格点 部で計測されるデータのみを用いて算出した COMAC 值においても，計測点 6 および計測点 14 において值が 相対的に小さくなっている. 以上より, 格点部での振動 計測による実鋼トラス橋の損傷位置の推定が可能である と考えられる. 計測点 10 の COMAC 值が小さくなって いる原因としては, $7.64 \mathrm{~Hz}$ 対応の損傷前後のモード形状 が，全データ(健全時 18 回，損傷時 15 回)を見ると計測 点 10 の付近でばらついていることが考えられるが，詳 細については引き続き検討する必要がある.

ただしモード形状の推定においては, 安定的に推定さ れているいくつかの振動数帯を主観的に見つけ，さらに その振動数に対応するモード形状を選ぶ必要がある。 ま た，健全時の着目モードが損傷後のどのモードに対応す るのかの判断は容易ではなく, 主観的な判断を必要とす ることから合理性に欠ける. なお参考として, 損傷前後 のモード形状の変化について, Modal Assurance Criterion (MAC)值について検討を行った結果を付録Bに示す。

\section{(3) MTSによる異常検知}

振動数および減衰定数に対し, MTS を適用し異常検 知を行う.

本研究では MTS の適用条件である「観測数(計測回 数 $) n>$ 項目数(計測点数) $k\rfloor$ を満たすことに配慮した上で, まず複数の計測点を一括して 1 つのグループを形成し， 損傷検知が可能であるかを調査する. 具体的には， Fig.10 に示す 2 つの計測点の組合せパターンについて MTS の適用を試みる．続いて，隣り合う2測点を 1つの グループとし $(k=2)$, 複数の計測点グループを用いるこ
とで，損傷位置推定の可能性についても検討を行う。す なわち, 観測点 1 と観測点 2 の推定パラメータを項目と して MTS を適用し, 次に測点 2 と測点 3 の推定パラメ 一タを項目とし MTS を適用する。この適用方法を測点 11 まで行い，損傷部材とは逆側の測点については測点 12 と測点 13 , 測点 13 と測点 14 を項目としMTS を適用 する. Table 3 に MTS の適用における損傷位置推定のた めの計測点グループをまとめる(Pattern III と称する). 本 研究では Table 3 に示寸 A から Lまでの 12 個のグループ それぞれで交差確認法を適用するため，それぞれのグル ープで設定される閾值にはばらつきが生じることになる
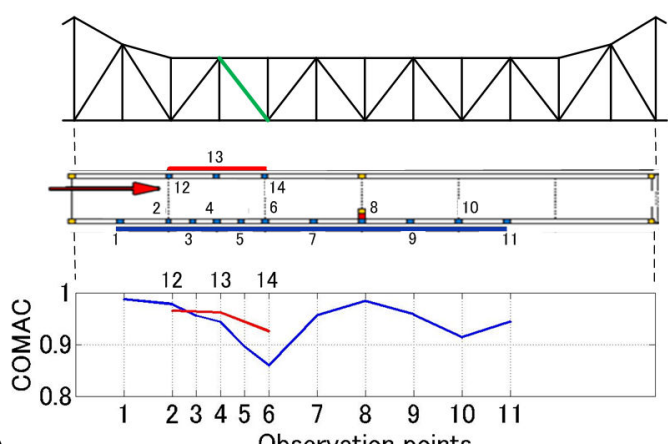

a) Observation points

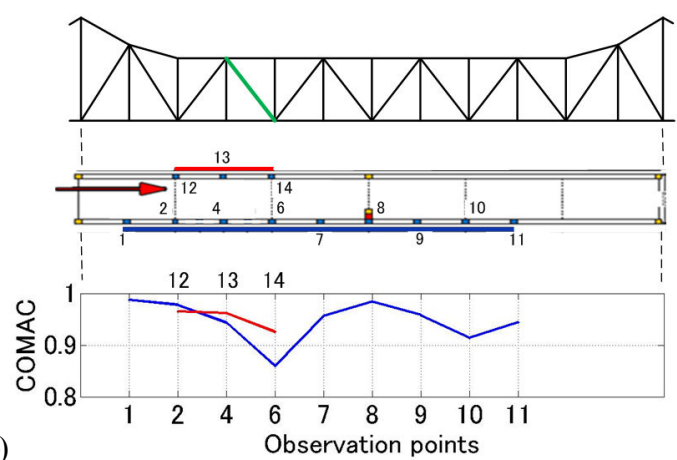

Fig.9 Mean COMAC of the observation span: a) all observation points; and $b$ ) observation points at panel points.

a)

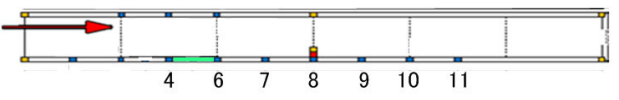

b)

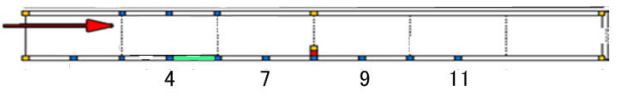

Fig.10 Grouping pattern: a) Pattern I $(k=7)$; and b) Pattern II $(k=4)$.

Table 3 Combination of evaluation item in MTS: Pattern III

\begin{tabular}{|c|c|c|c|c|c|c|c|c|c|c|c|c|}
\hline & \multicolumn{12}{|c|}{$(k=2)$. } \\
\hline & A & $\mathrm{B}$ & $\mathrm{C}$ & $\mathrm{D}$ & $\mathrm{E}$ & $\mathrm{F}$ & $\mathrm{G}$ & $\mathrm{H}$ & $\mathrm{I}$ & $\mathrm{J}$ & $\mathrm{K}$ & $\mathrm{L}$ \\
\hline \multirow{3}{*}{ Sensors } & 1 & 2 & 3 & 4 & 5 & 6 & 7 & 8 & 9 & 10 & 12 & 13 \\
\hline & $\&$ & $\&$ & $\&$ & $\&$ & $\&$ & $\&$ & $\&$ & $\&$ & $\&$ & $\&$ & $\&$ & $\&$ \\
\hline & 2 & 3 & 4 & 5 & 6 & 7 & 8 & 9 & 10 & 11 & 13 & 14 \\
\hline
\end{tabular}


が，グループごとのデータの性質は異なるのが一般的で あるため，このばらつきを統一する必要はないと考える. Pattern Iおよび Pattern II における，振動数および減衰定数 に MTS を適用した結果をそれぞれ Fig.11 および Fig.12 に示す．緑線は交差確認法における MD のトリム平均 から求まる閾值であり，各プロットの個数は観測数を表 す.なお Pattern I は項目数が 7 となるため, Fig.11 および Fig.12 に示す結果はいずれも観測数の多い SCN4 に対す る適用結果である. Pattern Iにおける MTS の適用におい て, 着目振動数 $1.96 \mathrm{~Hz}$ と, 着目振動数 $7.64 \mathrm{~Hz}$ の対応減 衰定数では，損傷時の MD が閾值を超える割合および
平均值が交差確認法における割合および平均值より小さ いことから，損傷検知が難しいことがわかる. しかし， Pattern I における着目振動数 $7.64 \mathrm{~Hz}$ と $1.96 \mathrm{~Hz}$ の対応減衰 定数および Pattem II における全ての振動特性については, 閾值を超える MD の割合と平均值が交差確認法による それらの值より大きくなり，損傷検知が可能である. 以 上の結果から，着目振動特性による検知可否にばらつき が見られるものの, 振動数および咸衰定数に MTS を適 用することで損傷検知は可能であると判断できる.また， Pattern I と Pattern II の観測数が等しい(共に健全時の観測 数 18, 損傷時の観測数 15)ことと, Pattern I $(k=7)$ よりも項 a)

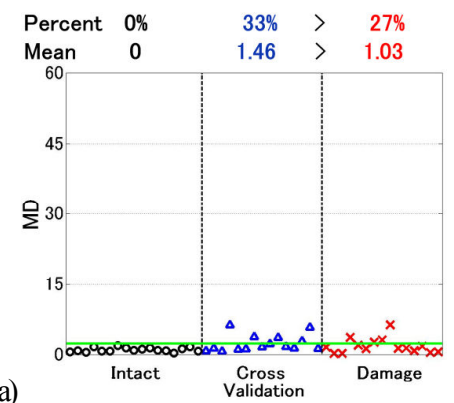

b)

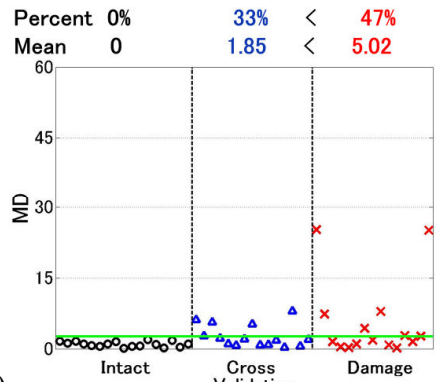

c)

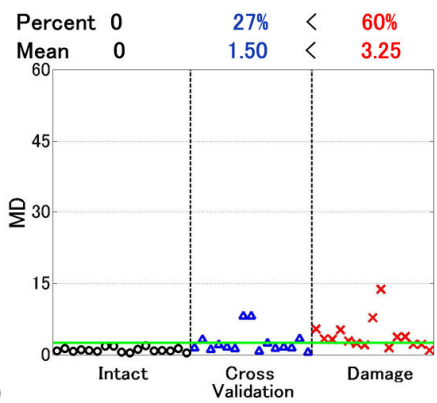

d)

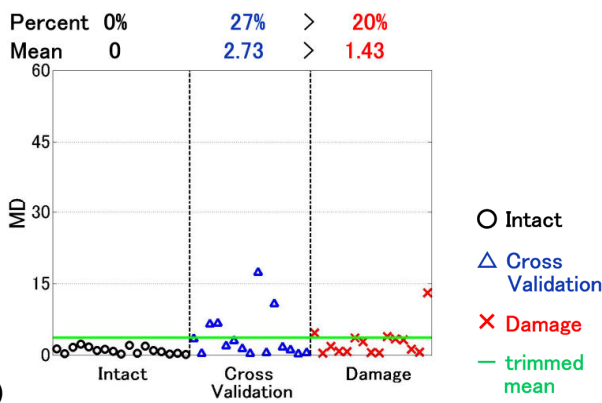

Fig.11 MTS under grouping Pattern I: a) frequency around $1.96 \mathrm{~Hz}$; b) frequency around $7.64 \mathrm{~Hz}$; c) damping constant corresponding to frequency $1.96 \mathrm{~Hz}$; and $\mathrm{d}$ ) damping constant corresponding to frequency $7.64 \mathrm{~Hz}$.

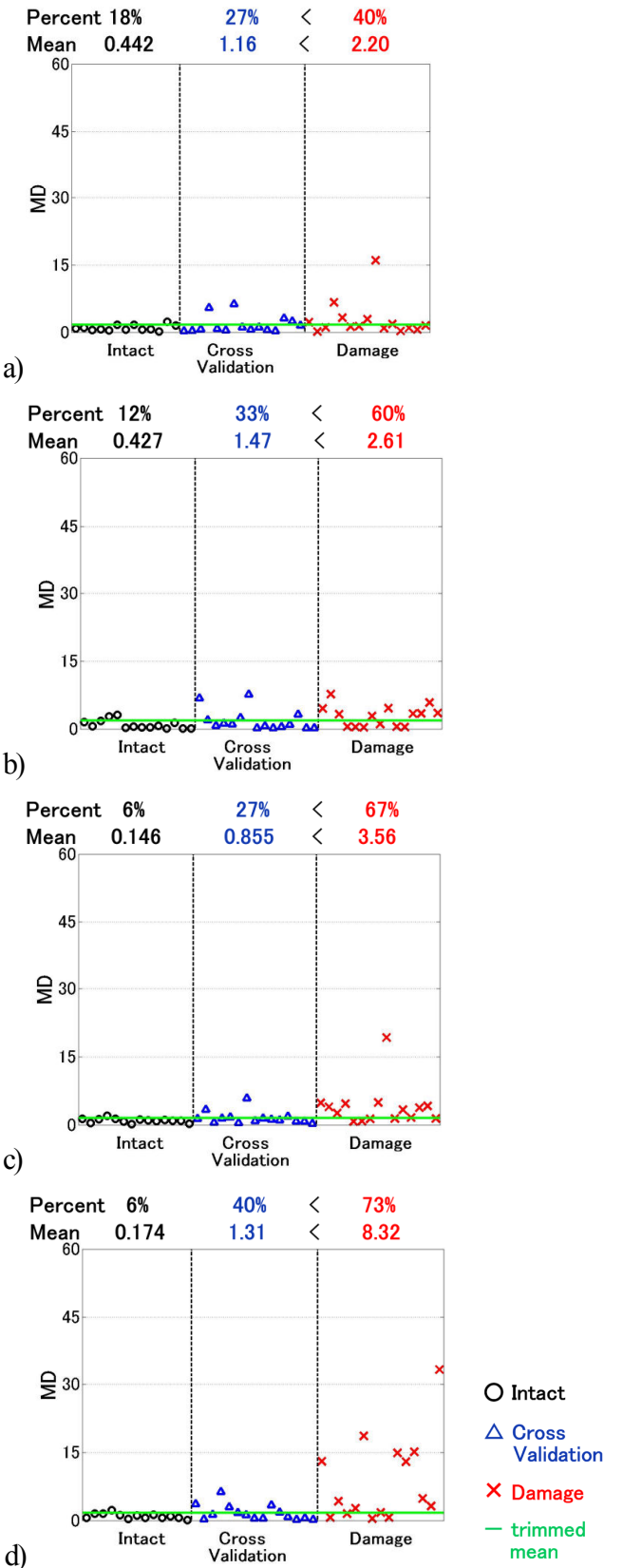

Fig.12 MTS under grouping Pattern II: a) frequency around $1.96 \mathrm{~Hz}$; b) frequency around $7.64 \mathrm{~Hz}$; c) damping constant corresponding to frequency $1.96 \mathrm{~Hz}$; and d) damping constant corresponding to frequency $7.64 \mathrm{~Hz}$. 
目数が少ない Pattern II $(k=4)$ の方が損傷検知を精度高く行 えていることを総合すると，項目数 $k$ に対する観測数 $n$ の比率 $n / k$ が大きい方が，損傷検知精度が高くなる可能 性を見出せる．ただし，Pattern I と Pattem II は，項目数お よびセンサ配置が異なるため，MTS を損傷検知に適用 する上での適切な項目数およびセンサ配置については引 き続き検討を続ける必要がある。

続いて，Table 3 に示寸隣り合う2 測点を 1つのグルー プ(Pattern III)として MTS を適用し，䦨值を超える MD の 割合と平均值を Fig.13〜 Fig.16に示す. SCN1 について, 振動数および咸衰定数に対する結果では，観測数が少な いために交差確認法の精度が悪く，3 章の判定基準を適 用寸るのは困難と考えられる. SCN2 についても振動数
および減衰定数のいずれにおいても，損傷位置付近の計 測点グループ D において，健全であると判定されるた め，損傷検知に有効ではない。一方，Fig.15 に示すよう に SCN3 の着目振動数 $1.96 \mathrm{~Hz}$ の対応減衰定数については, 損傷位置付近の計測点グループで異常と判定されるのに 対し，その他 $3 つ の$ 振動特性值については損傷位置と離 れた計測点グループで損傷と判定され，損傷位置の推定 は難しいことがわかる．なお，観測数が多い SCN4 にお いては，ほとんどの計測点グループで損傷であると判定 され，損傷検知が可能であると結論付けられる。しかし， MD が卓越する計測点グループが必ずしも損傷位置付近 の計測点を含む計測点グループ D および E ではないた め，損傷位置の推定には課題が残る.
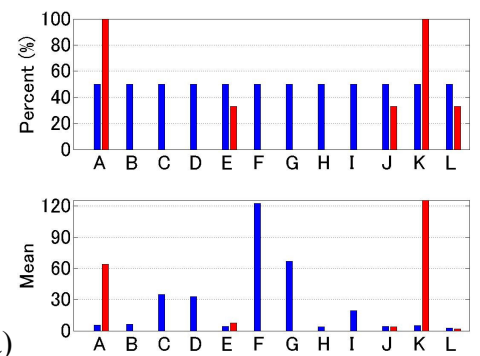

a)

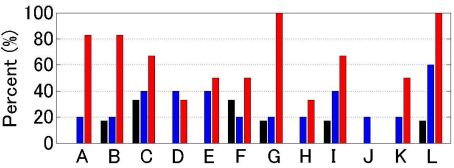

b)

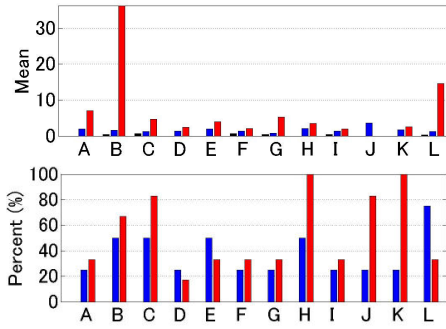

c)

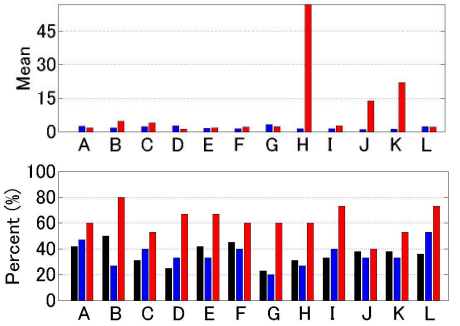

d)

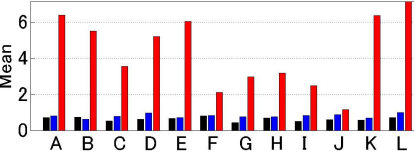

Fig.13 Percentage and mean value of MDs of the frequency around $1.96 \mathrm{~Hz}$ excessing the threshold under grouping Pattern III: a) $\mathrm{SCN} 1$; b) SCN2; c) SCN3; and d) SCN4.
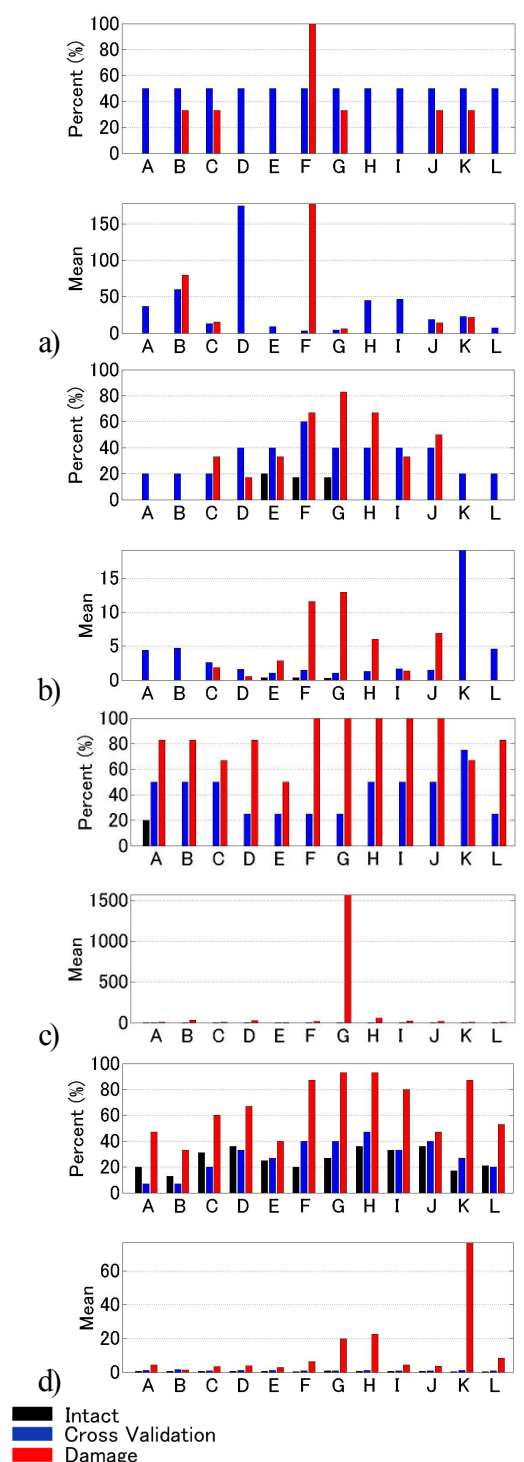

Fig.14 Percentage and mean value of MDs of the frequency around $7.64 \mathrm{~Hz}$ excessing the threshold under grouping Pattern III: a) $\mathrm{SCN} 1$; b) SCN2; c) SCN3; and d) SCN4.
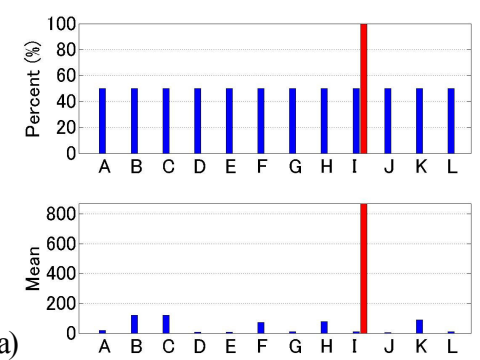

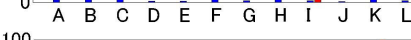
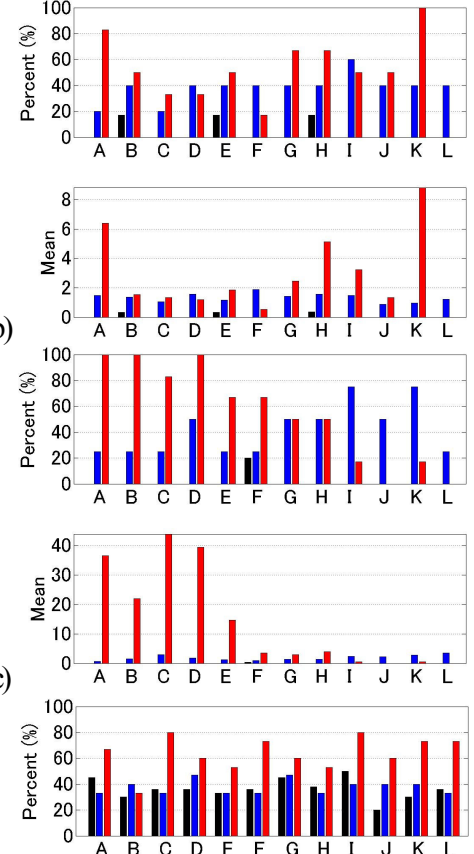

d)

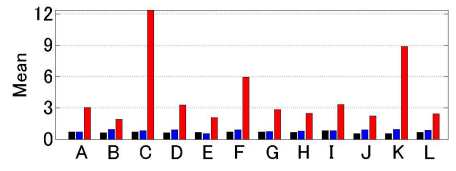

Cross Validatio

Fig.15 Percentage and mean value of MDs of the damping constant corresponding to the frequency around $1.96 \mathrm{~Hz}$ excessing the threshold under grouping Pattern III: a) SCN1; b) SCN2; c) SCN3; and d) SCN4. 

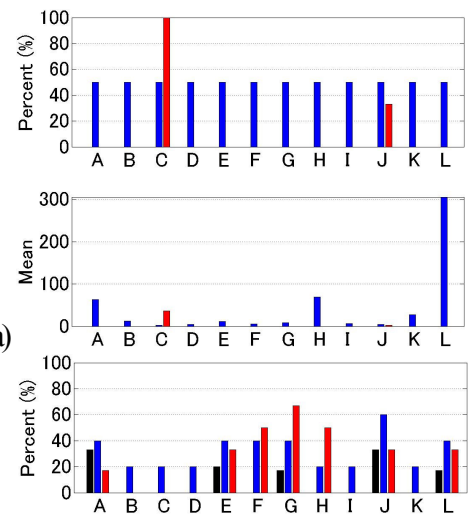

b)
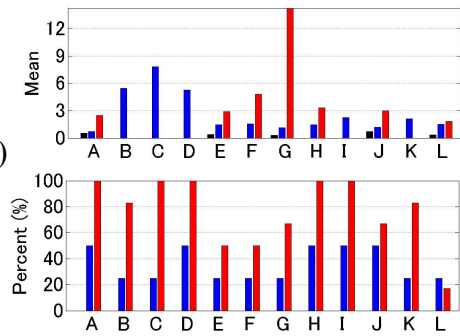

c)
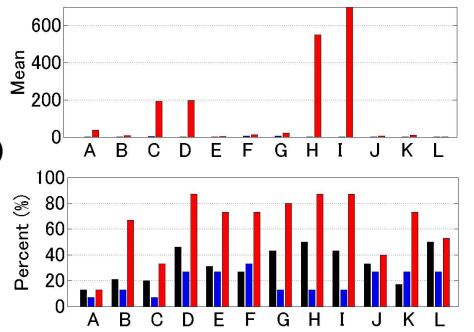

d)

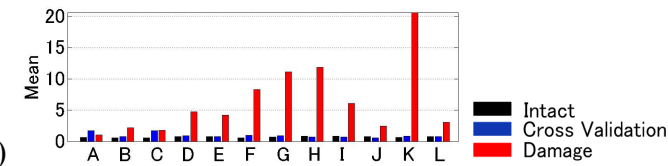

Fig.16 Percentage and mean value of MDs of the damping constant corresponding to the frequency around $7.64 \mathrm{~Hz}$ excessing the threshold under grouping Pattern III: a) SCN1; b) SCN2; c) SCN3; and d) SCN4.

\section{6. 線形システムパラメータに着目した異常診断}

\section{(1) AR 係数を用いた異常検知指標}

5 章にも述べたように, AR モデルによる振動特性の 推定においては AR 次数を推定結果より経験的に決定し ているため，最良線形予測子ではなく，また，橋梁の振 動特性と無関係な解も数多く推定されるため, モニタリ ング対象とする振動特性の抽出が困難となる場合がある. 抽出が可能であったとしても, 振動数, 隇衰定数, モー

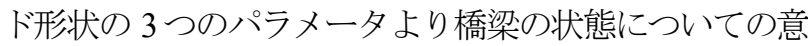
思決定を行う場合，どのパラメー夕に着目するか，また， 3 つのパラメータが異なる判定結果を導く場合など, 意 思決定における煩雑さもある。，そこで，線形システムパ ラメータである AR 係数の利用に着目し，損傷指標 DI (式(9)参照)を用いて検討を行う.

本研究では，最適 AR 次数の決定方法として AICを用
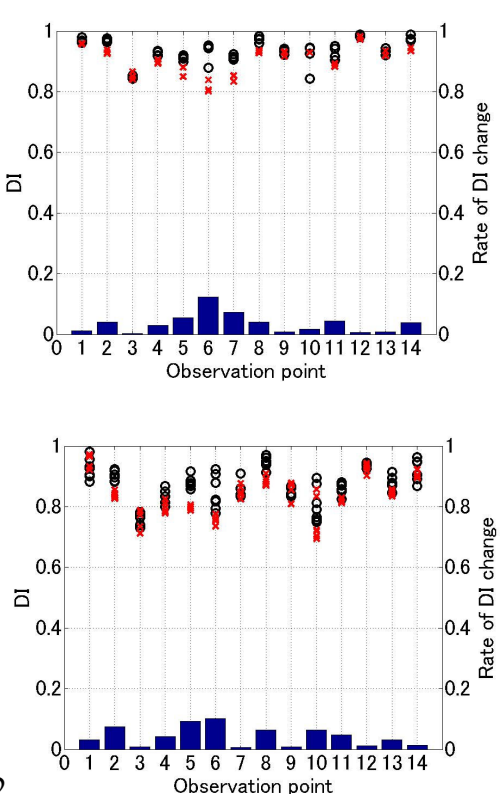

b) $\mathrm{SCN} 2$

c) $\mathrm{SCN} 3$

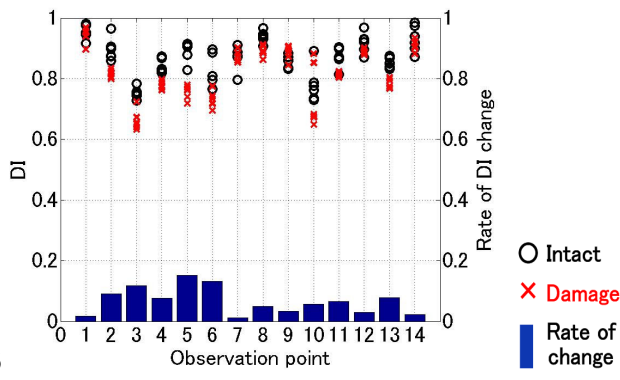

Fig.17 Estimated DI w.r.t. observation points.

いる. AICは次式で表される.

$$
\mathrm{AIC}=N \ln \left(2 \pi \hat{\sigma}_{M}^{2}\right)+N+2(M+1)
$$

ここで, $N$ はデータ数, $\hat{\sigma}_{M}^{2}$ は $M$ 次線形予測の予測誤差 の 2 乗平均, $M$ は $\mathrm{AR}$ 次数である. 次数を大きくすると 予測誤差は小さくなるが，次数が大きくなることで正確 なモデルを構築するわけではなく，観測值に含まれる誤 差までもモデル化することにつながる，そのため予測誤 差のみでモデルを評価するのは妥当でない，そこで，予 測誤差とモデル次数の関数である AIC において，AR 次 数を変化させ, $\mathrm{AIC}$ が最も小さくなるときの AR 次数を 用いる. これにより，先述した最良線形予測子でないと いう問題点を解決し，推定結果を経験的に判断して AR 次数を決定するのではなく，情報理論に基づいて AR 次 数の決定を行うことができる.

式(9)に基づき，各車両走行シナリオにおける健全時 および損傷時の DI の結果を Fig.17 に示す。黒丸は健全 時の DI，赤バツは損傷時の DI，青棒は損傷前後の DI の 変化率(式(A1)参照)を表す．本実験では，10km/h (SCN1) および $20 \mathrm{~km} / \mathrm{h}$ (SCN2)に比べ相対的に高速である $40 \mathrm{~km} / \mathrm{h}$ (SCN3)における推定結果の方が損傷による変化率が大き いことが分かる．また，損傷部材近傍の測点 5 および 6 
の損傷前後の DI の変化率が大きいことより，損傷検知 だけではなく損傷位置の推定も可能であると考えられる.

\section{(2) MTSによる異常検知}

次に, DI に対して MTS を適用し，異常検知を行う.

5(3)同様まず Fig.10 に示す 2 つ計測点組合せパターン について MTS を適用し, 損傷検知の可否を検証する.

続いて Table 3 に示すように A〜Lの 12 の計測点グルー プを作り，損傷位置の推定の可否についても検証する.

Fig.10 に示寸 Pattern Iおよび Pattem II に対する MTS の適 用結果を Fig.18a)および Fig.18b)に示す．5(3)同様，Fig.18 は SCN4 に対する適用結果である，閾值を超える割合は Pattern I と Pattem II の双方で 100\%であり，また，閾值を 超える MD の平均值についても, 振動数および減衰定 数に対する MTS の適用結果と比へ，損傷時と交差確認 法で大きな差が見られる。したがって，DI に対する MTS の適用は，振動数および減衰定数に対する MTS の 適用よりも損傷検知精度が高いと判断できる.

続いて, Table 3 に示すように隣り合う2測点を 1つの 計測点グループとして MTS を適用し，閾值を超える $\mathrm{MD}$ の確率および平均值を Fig.19に示す.

DI に対しても SCN1 においては観測数が少ないために 交差確認法の精度が悪く, 3 章の判定基準を適用するの は困難であると言える．SCN2，SCN3 および SCN4 につ いては，多くの計測点グループで損傷時の MD が䦨值 を超える割合が $100 \%$ に近くなっており，損傷位置付近 の計測点グループ C，D および E はほとんどが 100\%で ある．閾值を超える MD の平均值についても多くの計 測点グループで交差確認法による結果と比べ損傷時の方

a)

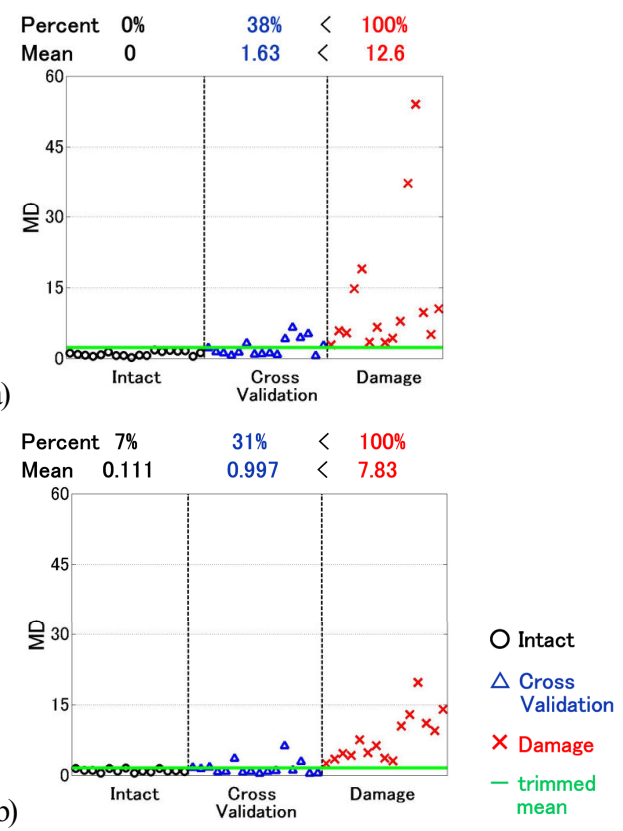

Fig.18 MD of DI: a) Pattern I; and b) Pattern II.
が大きくなっており，特に計測点グループ C，Dおよび Eの值が相対的に大きくなっている. したがって，DIに 対する MTS の適用は損傷そのものの検知だけでなく, 損傷位置の推定にも役立つ可能性があることを確認でき る. 特に, SCN3 において, 計測点グループ C, D およ び $\mathrm{E}$ のほとんどの MD が閾值を超え，その平均值が相 対的に大きくなる傾向が見受けられる.

なお，本研究における実橋を用いた損傷実験では損傷 位置付近のセンサ配置が密になるように設定しているが， 実際には損傷位置は未知である。そこで，Fig.3 に示す 観測点 3 および 5 のデータを用いず，格点部の観測点で 得られるデータのみに対して MTS を適用し, 損傷位置 の推定を試みる．Table 4 に項目の組合せをまとめ(Pattern IV と称する)，Fig.20にMTS を適用した結果を示寸.

$\mathrm{SCN} 1$ では, 観測数が 4 と少ないため交差確認法の精 度が悪く, 3 章の判定基準を適用して損傷を検知するこ

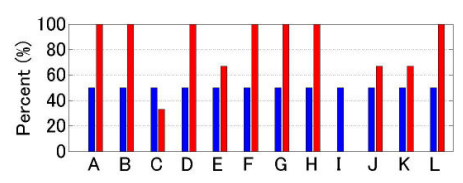

a)

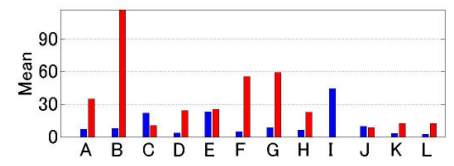

b)

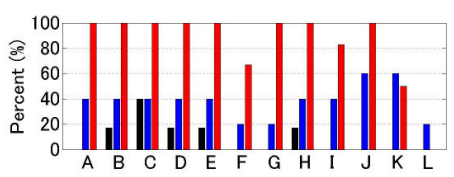

c)
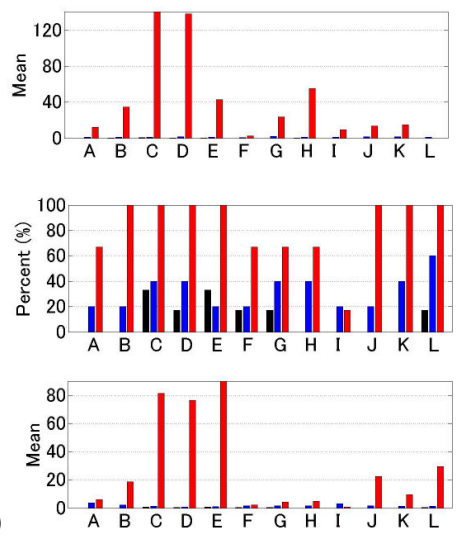

d)

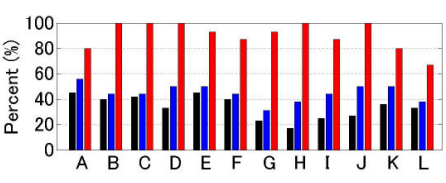

Fig.19 Percentage and mean value of MDs of DI excessing the threshold under grouping Pattern III: a) SCN1; b) SCN2; c) SCN3; and d) SCN4. 
Table 4 Combination of evaluation item in MTS: Pattern

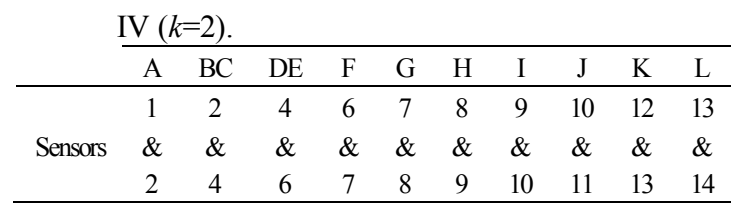

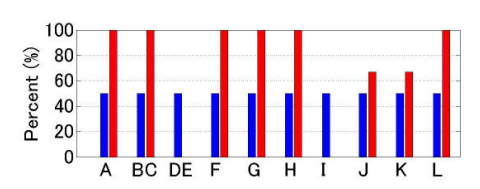

a)
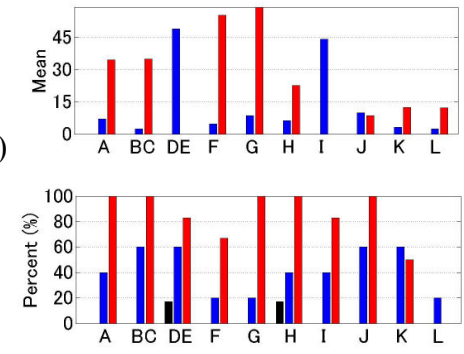

b)

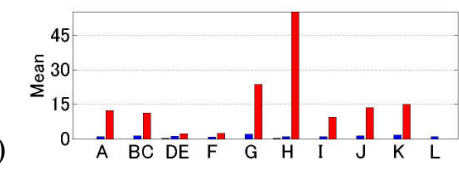

c)

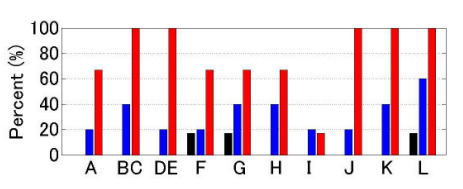

d)
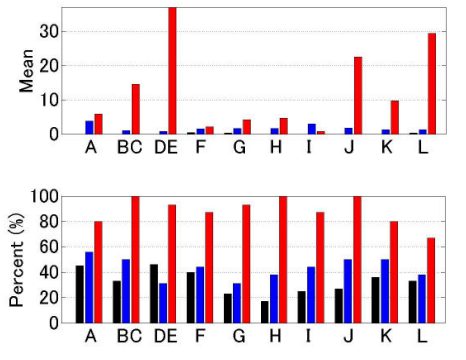

Fig.20 Percentage and mean value of MDs of DI excessing the threshold under grouping Pattern IV: a) SCN1; b) SCN2; c) SCN3; and d) SCN4.

とは困難である. SCN2，SCN3 および SCN4 において， 損傷時の MD が閾值を超える割合に関しては，Pattern III の適用結果より多少減るが，多くの計測点グループで 100\%に近くなっている. しかし, 閾值を超える MD の 平均值については Pattern III における適用結果と異なる 傾向を示寸．特に，SCN2 については損傷位置から離れ た計測点グループ Gおよび $\mathrm{H} の \mathrm{MD}$ が卓越している.

一方，SCN3 については損傷位置付近である計測点グ ループ $\mathrm{DE} の \mathrm{MD}$ が最も卓越しているが，双方の影響を 受ける SCN4 については SCN2 の影響を受け, 卓越する
$\mathrm{MD}$ が計測点グループ $\mathrm{G}$ および $\mathrm{H}$ となっている. SCN2 に対する MTS の適用よりも走行速度が速い SCN3 に対 寸る適用の方が高精度で損傷位置推定を実現できる傾向 はFig.19に示す Pattern IIIにおいても見られる. 速い走行 速度による加振力の増加が損傷位置推定の精度を高めた と推察しているが，走行速度と損傷位置推定精度の関連 性については，今後橋梁交通振動シミュレーション等を 行い，その関連性を明らかにするためのさらなる検討を 行う必要がある.

\section{7. 結論}

本研究では, 車両走行時の橋梁振動データから橋梁の 振動特性を同定し，その特性に着目した異常検知手法お よび，車両 - 橋梁連成振動系線形システムパラメータに 着目した異常検知手法のそれぞれについて実橋梁への適 用可能性を検討した，以下にその結果をまとめる.

(1) 交通振動データから推定されるモード形状を用い, COMAC の適用による損傷位置推定の可能性を確 認した.このことから, 安定的な振動モードの同 定が出来れば, COMAC による損傷位置同定は有 効であると言える，ただし，どの振動モードを選 定するかには主観的な判断が必要である.

(2) 振動数および咸衰定数に対し MTS を適用した結果, 損傷検知については高い可能性を確認したが，損 傷位置については推定が困難である.

(3) DI について，車両速度 $10 \mathrm{~km} / \mathrm{h}$ おび $20 \mathrm{~km} / \mathrm{h}$ に比べ 相対的に高速である $40 \mathrm{~km} / \mathrm{h}$ において，損傷前後の 変化率が最も大きい結果となった。

（4） DI に対し MTSを適用した結果，損傷検知について は振動特性に対する MTS の適用結果に比へ，損傷 時の MD が閾值を超える割合および閾值を超える $\mathrm{MD}$ の平均值の双方が大きくなることを確認した. すなわち振動特性およびそれらに対する MTS の適 用による異常検知に比べ, 損傷指標 DI および DI に対する MTS の適用による異常検知がより客観的 かつ高精度であることを確認できた。

（5）ＤI による損傷位置の推定については，損傷部材付 近に密にセンサを配置することで, 振動特性に対 する適用結果と比べて相対的に高精度で損傷位置 を推定できることが確認できた。しかし，トラス 格点部程度の疎な計測点のみを用いる場合, 損傷 位置の推定が困難であるとの結果が得られた。 な お，いずれの場合においても，車両走行速度 $20 \mathrm{~km} / \mathrm{h}$ に比べ相対的に高速である $40 \mathrm{~km} / \mathrm{h}$ のシナリ オにおいて, MTS の適用による損傷位置の推定精 度が高い結果となった。 
今後は，異常検知のための最適センサ配置や最小計測 点数についての検討を行う必要がある. また，損傷位置 推定の精度向上も今後の課題である.

謝辞：本研究における実橋損傷実験は，対象橋梁の管 理者である大阪府および土木学会関西支部平成 21 年度 共同研究グループ「橋梁の維持管理へのモニタリング技 術の適用に関する研究会」のご協力のもと実現された. 実験及びデータ整理にご尽力頂いた元大学院生である伊 勢本遼氏(株式会社 竹中工務占)に感謝を表する。 また, 研究の一部において, 科学研究費補助金(基礎研究(B), 課題番号 24360178)を用いた。ここに記して謝意を示す.

\section{付録 $A$}

各車両走行シナリオにおける $1.96 \mathrm{~Hz}$ 近傍振動数およ び対応する減衰定数の損傷前後の変化を Fig.A1 および Fig.A2 に示寸. 図中の黒丸は健全時の推定值を，赤バツ は損傷時の推定值を，青色の棒グラフは，式(A1)で定義 する損傷前後の推定パラメータの変化率を示している.

変化率 $($ Rateof change $)=\frac{\left|X_{\text {Intact }}-X_{\text {Damage }}\right|}{X_{\text {Intact }}}$

a) SCN1
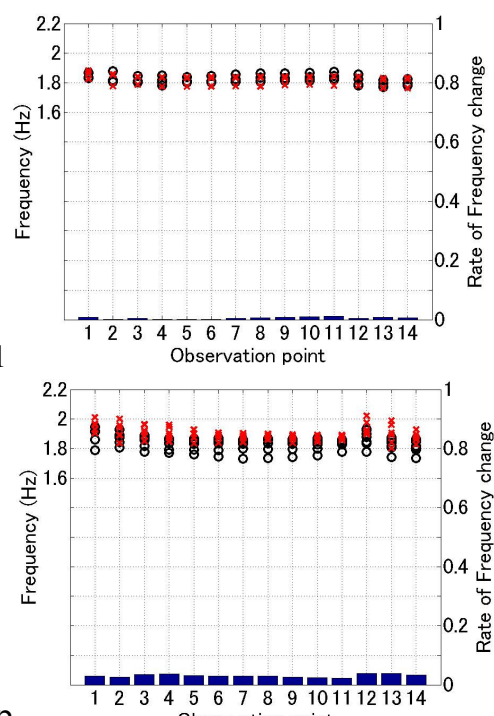

b) $\mathrm{SCN} 2$

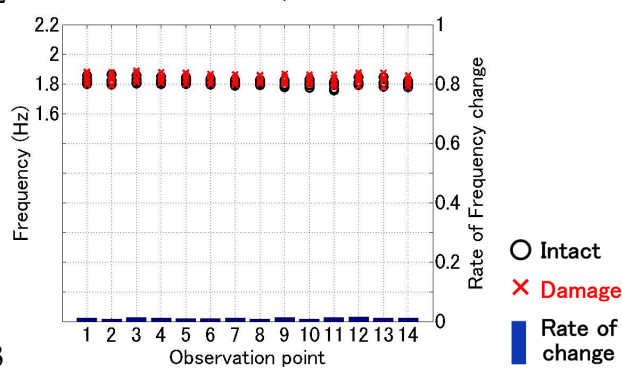

c) $\mathrm{SCN} 3$

Estimated system frequency around $1.96 \mathrm{~Hz}$ w.r.t. observation points.
ここに，Xは推定パラメータの平均值である.

振動数について, 車両走行速度が $20 \mathrm{~km} / \mathrm{h}$ (SCN2)の場 合，損傷による変化が最も大きいが，その差は微小であ り，この結果だけで損傷検知を行うことは困難であると 考えられる. 一般的に，損傷により振動数は減少するが, 本実験では, 損傷により振動数が増加する傾向にある. 原因については特定できていない，一方，減衰定数につ いては，振動数に比べ変化率は大きいが，推定值そのも ののばらつきが大きく推定結果の変化率だけで損傷検知 を行うことは，振動数と同様困難である．なお， $7.64 \mathrm{~Hz}$ 近傍の振動数およびそれに対応する減衰定数のいずれに ついても推定結果のばらつきが大きく, 損傷検知を行う ことは困難であった.

\section{付録 B}

MAC 值はモード形状の相関のみを算出する指標であ るため，損傷位置の推定を行うことはできない，MAC 值は式(B1)で定義される 0 から 1 の值を持ち，1 に近い ほど相関が強いことを意味する.

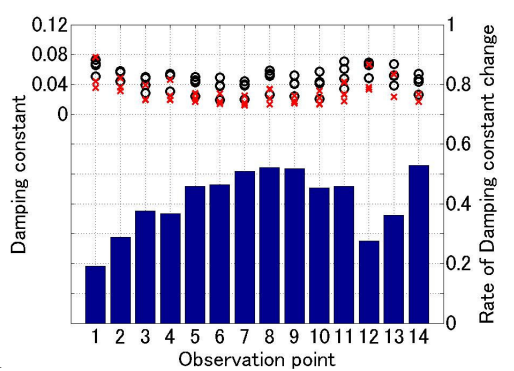

a) $\mathrm{SCN} 1$

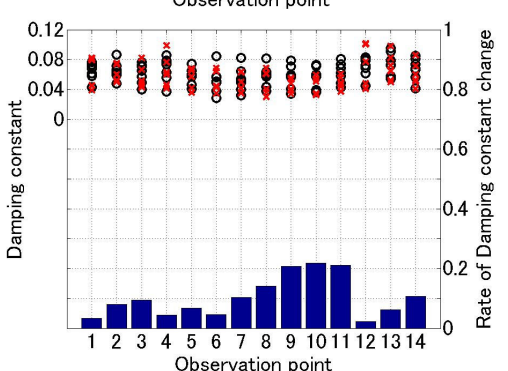

b) $\mathrm{SCN} 2$

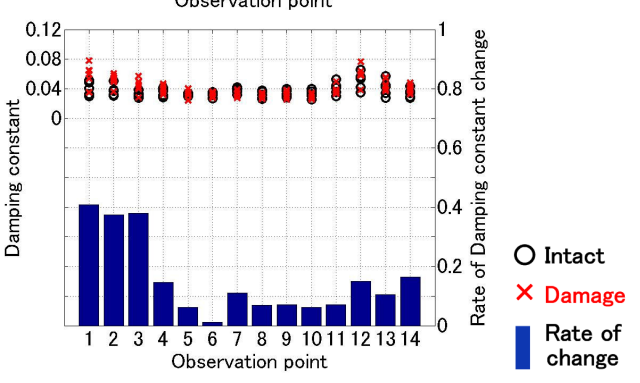

Fig.A2 Estimated system damping constant corresponding to the frequency around $1.96 \mathrm{~Hz}$ w.r.t. observation points. 
Table B1 Average MAC in Cross Validation and average MAC between Intact and Damage.

\begin{tabular}{|c|c|c|}
\hline $\begin{array}{c}\text { Average } \\
\text { MAC } \\
\begin{array}{c}\text { Focusing } \\
\text { mode }\end{array}\end{array}$ & $\begin{array}{c}\text { Between } \\
\text { Intact mode shapes } \\
\text { in Cross-Validation }\end{array}$ & $\begin{array}{c}\text { Between } \\
\text { Intact and Damage } \\
\text { mode shapes }\end{array}$ \\
\hline $\begin{array}{c}1^{\mathrm{s}} \text { dominant mode } \\
\text { (around 1.96Hz) }\end{array}$ & 0.991 & 0.990 \\
\hline $\begin{array}{c}2^{\text {nd }} \text { dominant mode } \\
\text { (around 7.64Hz) }\end{array}$ & 0.926 & 0.830 \\
\hline
\end{tabular}

$$
\operatorname{MAC}(i)=\frac{\left\|\left\{\boldsymbol{\varphi}_{i}^{I n}\right\}^{T}\left\{\boldsymbol{\varphi}_{i}^{D m}\right\}\right\|^{2}}{\left\|\left\{\boldsymbol{\varphi}_{i}^{I n}\right\rangle\right\|^{2}\left\|\left\{\boldsymbol{\varphi}_{i}^{D m}\right\}\right\|^{2}}
$$

Table 1 に示すように，健全時の走行回数は 18 回，損傷 時の走行回数は 15 回である. そこで本研究ではまず健 全時における 18 個の $i$ 次モード形状に対して交差確認 法を適用し, 18 個の $\mathrm{MAC}$ 值の平均值を求める. 次に, 健全時における 18 個の $i$ 次モード形状の平均モード形 状を求め, この平均モード形状と損傷時における 15 個 の $i$ 次モード形状それぞれとの MAC 值を算出し，その 平均值を求めた。 結果を Table B1 に示す. 1 次および 2 次モードのいずれでも交差確認法における MAC 值より, 健全時と損傷時の MAC 值が小さいことがわかる．特に 2 次モードについてはその傾向が顕著であり, MAC 值 によっても損傷検知の可能性があることがわかる.

\section{参考文献}

1) 国土交通省道路局：道路統計年報 2011，橋梁現況の 推移, 2011.

2) 米国ミネアポリス橋梁崩壊事故に関する技術調査 団: 米国ミネアポリス橋梁崩壊事故に関する技術調 查報告, 2007 .

3) 国土交通省：鋼橋 (上部構造)の損傷事例, www.mlit. go.jp/road/sisaku/yobohozen/yobo3_1_1.pdf

4) Doebling, S. W., Farrar, C. R., Prime, M. B. and Shevitz, D. W.: Damage identification and health monitoring of structural and mechanical systems from changes in their vibration characteristics: A Literature Review, Los Alamos National Laboratory report, LA-13070-MS, 1996.

5) Peeters, B. and De Roeck, G.: One-year monitoring of the Z24-Bridge: environmental effects versus damage events, Earthquake Engineering and Structural Dynamics, Vol. 30, No. 2, pp. 149-171, 2011.

6) Deraemaeker, A., Reynders, E., De Roeck, G. and Kullaa, J.: Vibration-based structural health monitoring using output-only measurements under changing environment, $\mathrm{Me}$ chanical Systems and Signal Processing, Vol. 22, No. 1, pp. 34-56, 2007.

7) Zhang, Q. W.: Statistical damage identification for bridges using ambient vibration data, Computers and Structures, Vol. 85, No. 7-8, pp.476-485, 2007.

8) Dilena, M. and Morassi, A.: Dynamic testing of damaged bridge, Mechanical Systems and Signal Processing, Vol. 25, pp. 1485-1507, 2011.
9) 古川愛子, 大塚久哲, 梅林福太郎：構造物の損傷に 伴う振動特性の変化に関する実験的考察, 地震工学 論文集，土木学会，Vol.28, No.19, pp.1-9, 2005.

10) Wenzel, H. and Pichler, D.: Ambient Vibration Monitoring, John Wiley \& Sons, p. 77, 2006.

11) 金哲佑, 川谷充郎：単一車両による橋梁振動データ を用いた橋梁の健全度評価, 鋼構造論文集, 日本鋼 構造協会，第 15 巻，第 58 号, pp.37-46, 2008.

12) Gul, M. and Catbas, F. N.: Statistical pattern recognition for structural health monitoring using time series modeling: Theory and experimental verifications, Mechanical System and Signal Processing, Vol. 23, pp. 2192-2204, 2009.

13) 服部洋, 古田均, 野村泰稔, 中津功一朗, 石橋健 : AdaBoost による振動予測を用いた橋梁へルスモニタ リングシステムの構築に関する実験的研究, 土木学 会論文集 A2 (応用力学), Vol. 67, No. 2, pp. I_825I 832, 2011.

14）金哲佑, 伊勢本遼, 川谷充郎, 杉浦邦征 : 模型桁車 両走行実験における異常診断の可能性の検討, 土木 学会論文集 A2 (応用力学), Vol. 67, No. 2, pp. I 833-I 842, 2011.

15）川谷充郎, 嶋田玲志：桁橋の自動車走行による不規 則振動と衝撃係数, 土木学会論文集, No. 398/I-10, pp. 303-309, 1988.

16) Kim, C. W., Kawatani, M. and Kim, K. B.: Threedimensional dynamic analysis for bridge-vehicle interaction with roadway roughness, Computers and Structures, Vol. 83, No. 19-20, pp. 1627-1645, 2005.

17) Kim, C. W. and Kawatani, M.: Pseudo-static approach for damage identification of bridges based on coupling vibration with a moving vehicle, Structure and Infrastructure Engineering, Vol. 4, No. 5, pp. 371-379, 2008.

18) Kim, C. W., Kawatani, M. and Hao, J.: Modal parameter identification of short span bridges under a moving vehicle by means of multivariate AR model, Structure and Infrastructure Engineering, Vol. 8, No. 5, pp.459-472, 2012.

19) Kim, C. W., Isemoto, R., Sugiura, K. and Kawatani, M.: Structural Fault Detection of Bridges based on Linear System Parameter and MTS Method, J. of JSCE, Vol. 1, No. 1, pp. 32-43, 2013.

20) 吉岡勉, 伊藤信, 山口宏樹, 松本泰尚 : 鋼卜ラス橋 の斜材振動連成とモード減衰変化を利用した構造健 全度評価，土木学会論文集 A, Vol. 66, No. 3, pp. 516534, 2010.

21) Gersch, W., Nielsen, N. N. and Akaike, H.: Maximum likelihood estimation of structural parameters from random vibration data, J. of Sound and Vibration, Vol. 31, No. 3, pp. 295-308, 1973.

22) Shinozuka, M., Yun, C. B. and Imai, H.: Identification of liner structural dynamic system, J. Eng. Mech. Div., ASCE, Vol. 108, No. 6, pp. 1371-1390, 1982.

23) Hoshiya, M. and Saito, E.: Structural identification by extend Kalman filter, J. Eng. Mech., ASCE, Vol. 110, No. 12, pp. 1757-1770, 1984.

24) Wang, Z. and Fang, T.: A time-domain method for identifying model parameters, J. of Appl. Mech., ASME, Vol. 53, No. 3, pp. 28-32, 1986.

25) He, X. and De Roeck, G.: System identification of mechanical structures by a high-order multivariate autoregres- 
sive model, Computers and Structures, Vol. 64, No. 1-4, pp. 341-351, 1997.

26) 岡林隆敏, 奥松俊博, 中宮義貴 : 高精度自動振動数 推定システムによる構造物損傷の検知に関する実験 的研究, 構造工学論文集, Vol. 51A, pp. 479-490, 2005.

27) 岡林隆敏, 奥松俊博, 中宮義貴 : 常時微動に基づく $\mathrm{AR}$ モデルによる構造物振動数の高精度自動推定，土 木学会論文集, No. 759/I-67, pp. 271-282, 2004.

28) Akaike, H.: Information theory and extension of the maximum likelihood principle, Proc. $2^{\text {nd }}$ Int. Symp. on Information theory, Petrov, B. N. and Csaki. F., Tsahkadsov, Armenia, USSR, pp. 267-281, 1973.

29) 岡林隆敏, 中忠資, 奥松俊博, 郝婕馨 : 多次元 $\mathrm{AR}$ モデルを用いた常時微動による橋梁振動特性の推定 と推定精度の検討, 土木学会論文集 A, Vol. 64, No. 2, pp. 474-487, 2008.

30) Taguchi, G. and Jugulum, R.: New trends in multivariate diagnosis, Indian Journal of Statistics, Vol. 62, Series B, pp. 233-248, 2000.

31) Nair, K. K., Kiremidjian, A. S. and Law, K. H.: Time series-based damage detection and localization algorithm with application to the ASCE benchmark structure, $J$. of Sound and Vibration, Vol. 291, No. 1-2, pp. 349-368, 2006.

32) Ljung, L.: System Identification-Theory for the User, $2^{\text {nd }}$ edition, PTR Prentice Hall, Upper Saddle River, N. J., 1999.

33) Brinker, R., Zhang, L. and Andersen, P.: Modal identification from ambient response using frequency domain decomposition, IMAC XVIII, San Antonio, USA, 2000.

34) Lieven, N. A. J. and Ewins, D. J.: Spatial Correlation of mode shapes, the Co-ordinate Modal Assurance Criterion (COMAC), Proc. the $6^{\text {th }}$ Int. Modal Analysis Conference, Vol. 1, pp. 690-695, 1988.

(2013.4.23 受付)

\section{STRUCTURAL DAMAGE DETECTION OF A MULTI-SPAN CONTINUOUS STEEL-TRUSS BRIDGE FOCUSING ON TRAFFIC VIBRATION}

\section{Chul-Woo KIM, Sotaro KITAUCHI, Kunitomo SUGIURA, Mitsuo KAWATANI and Masayoshi KAI}

This study is intended to investigate feasibility of bridge health monitoring utilizing dynamic parameters and a linear system parameter of a time series model identified from traffic-induced vibration data of bridge through a moving vehicle experiment on a real continuous steel-truss bridge. In addition to the natural frequency and damping constant of the bridge, this study adopts Damage Indicator (DI) which consists of autoregressive (AR) coefficients as a parameter to detect possible anomaly of the bridge. First, this study assesses the changes in frequency, damping constant, mode shape and DI. Second, Mahalanobis-Taguchi System (MTS) is used to judge potential changes in frequency, damping constant and DI. DI can be estimated stably and its change due to damage is relatively large. Mahalanobis-Taguchi System (MTS) is successfully applied to make a decision on not only bridge condition but damage location. Observation demonstrates feasibility of structural diagnosis of bridges from the identified system parameters. However, the sensor location is still an important factor in identifying damage location which needs further investigations. 